\title{
PARTSI - A NEW PROMISING AREA FOR THE INVESTIGATION OF LATE BOREAL AND EARLY ATLANTIC WATER LEVEL CHANGES OF THE BALTIC SEA
}

\author{
Anto RAUKAS, Elvi TAVAST, and Anatoly MOLODKOV
}

Geoloogia Instituut (Institute of Geology), Estonia pst. 7, EE-0001 Tallinn, Eesti (Estonia)

Received 17 July 1995, accepted 18 December 1995

Abstract. The large gravel pit at Partsi on Hiiumaa Island, Estonia, exposes a long section of obliquely laminated well rounded but poorly sorted sandy gravel, pebbles, and cobbles, containing freshwater molluses (Limnaea baltica, Ancylus fluviatilis, Bithynia tentaculata, etc.) in its lower part and brackish-water molluscs (different species of Cerastoderma, Macoma baltica, etc.) in the upper part. A Lymnaea baltica shell sample from freshwater Ancylus sediments has yielded an electron-spin-resonance (ESR) calendar age of $8860 \pm 700 \mathrm{yr}$ BP which corresponds to c. 8000 conventional noncorrected radiocarbon yr BP. A Cerastoderma glaucum shell sample from the brackish-water Litorina sediments has given an ESR age of $6310 \pm 720 \mathrm{yr} \mathrm{BP}$ or about $5500{ }^{14} \mathrm{C}$ yr BP. The data from the Partsi section suggest that water level in the Ancylus Lake dropped $30 \mathrm{~m}$ before the following Litorina transgression. About one-third of the lowering of the water level was probably caused by land uplift.

Key words: malacofauna, mollusc shells, electron-spin-resonance (ESR) dating, Baitic Sea, Hiiumaa Island, Ancylus Lake, Litorina Sea.

\section{INTRODUCTION}

For a long time, the sandy-gravelly plain in the Paluküla-Partsi area in northeastern Hiiumaa Island (Fig. 1) was considered glaciofluvial in origin. In 1989, a geological excursion of geologists from the Baltic States visited the island. During the excursion, subfossil mollusc shells were discovered in the steeply dipping layer of coarse gravel containing pebbles and cobbles in Partsi gravel pit, and afterwards also in the deeper-lying finer sandy sediments, which is indicative of the marine origin of the plain. Among the molluscs, collected by G. Eltermann and identified by $\mathrm{H}$. Kessel (unpublished data), the following typical Ancylus Lake species were represented: Ancylus fluviatilis, Lymnaea lamarcki, Radix ovata (or Lymnaea baltica), Bithynia tentaculata, Valvata piscinalis, and Pisidium pleifferi. On the basis of the evidence derived it was concluded that the accumulative form in the lee of the Paluküla height had developed as a spit during the Ancylus Stage, although the absolute heights of the formation did not fit with the known Ancylus levels on Hiiumaa Island (Kents, 1939). According to Raukas et al. (1994), the spit had been finally formed by the waves of the Litorina Sea, however, 
the idea was not supported by stratigraphical evidence. In the summer of 1994, a rich subfossil Litorina mollusc fauna above the Ancylus fauna was found in the uppermost part of Partsi gravel pit (Raukas \& Ratas, 1995; Tavast, 1995), which confirmed the conjecture of Kessel and Raukas (Кессел \& Раукас, 1967) about the catastrophic lowering of the Ancylus Lake (phase $A_{V I}$ ) before the Litorina/Mastogloia transgression.

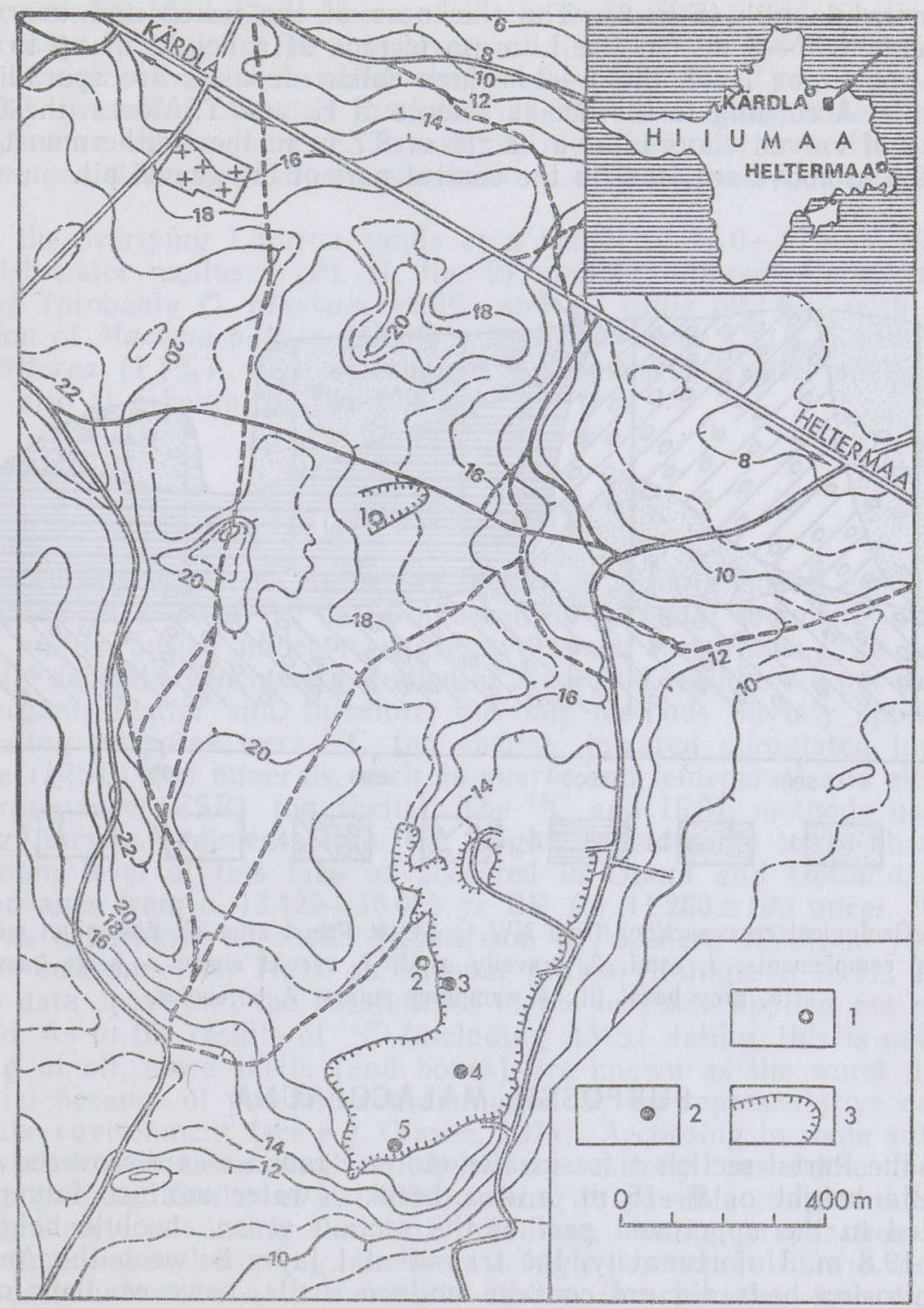

Fig. 1. Location and topography of the study area. 1, Litorina fauna sampling places; 2, Ancylus fauna sampling places; 3 , gravel pit. 


\section{LOCATION AND GEOLOGY OF THE PARTSI SECTION}

The gravel pit at Partsi in the northeastern part of Hiiumaa Island, $10 \mathrm{~km} \mathrm{SE}$ of Kärdla, exposes a long section of inclined bedded sandy gravel, pebbles and cobbles (P1. I, fig. 1), which are well rounded (coefficient of roundness 2.3), but poorly sorted. Among the clasts local carbonate rocks prevail ( $96 \%$ on an average). Most of pebbles and cobbles are more or less isometric (coefficient of flatness 1.62), which for a long time was the main reason for genetical misinterpretation of the beds mentioned. Coarse-grained sediments are underlain by medium-grained sand with interlayers of gravel (Pl. I, fig. 2).

The Partsi spit was formed above the more than ten metre thick glaciolacustrine varved clays in the lee of the Paluküla bedrock island and morainic hill (Fig. 2). The thickness of the beach and nearshore sediments is $7-8 \mathrm{~m}$. On the Litorina terrace at a height of up to $18-$ $20 \mathrm{~m}$ above sea level, the $1-2$-m-thick eolian deposits are sporadically traceable. According to the measurements of $\mathrm{H}$. and T. Moora, the upper surface of varved clays is at a height of $8.7 \mathrm{~m}$ in the southernmost part and $12.9 \mathrm{~m}$ above sea level in the central part of the gravel pit.

NW

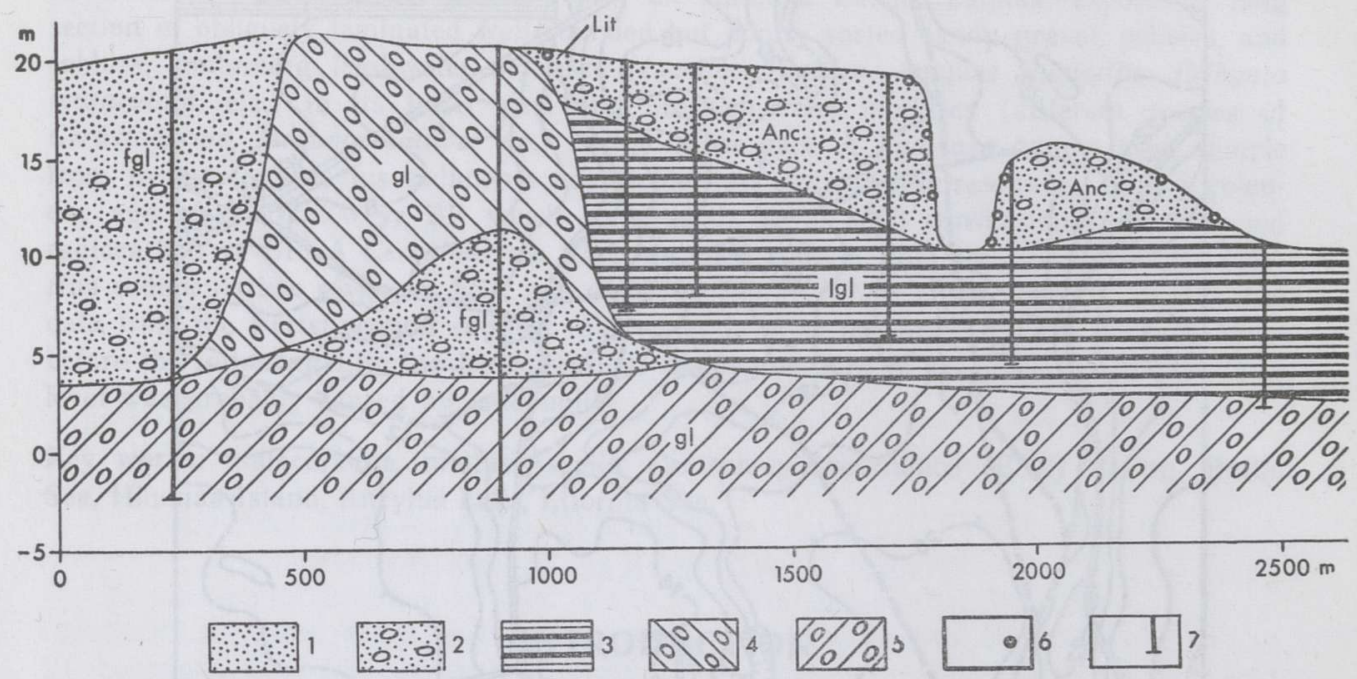

Fig. 2. Geological cross-sections from NW to SE at Partsi after G. Eltermann with the authors' complements: 1 , sand; 2 , gravelly sand; 3 , varved clays; 4 , beige basal till; 5 , grey basal till; 6 , sampling points; 7 , boreholes.

\section{SUBFOSSIL MALACOFAUNA}

In the Partsi section a freshwater mollusc fauna was discovered at an absolute height of 9-15 m, and a brackish-water mollusc fauna was detected in the uppermost part of the section at an absolute height of 15.6-19.8 m. Unfortunately, the transitional layer between the Ancylus and Litorina beds did not contain mollusc shells, however, their occurrence in some other part of the section is not excluded. In mainland Estonia (Risti, Vihterpalu) and on Muhu Island (Võlla), the sediments of that level comprise besides the typical Ancylus forms, such as Ancylus fluviatilis, Lymnaea baltica, Bithynia tentaculata, and Pisidium amni- 
cum, also the slightly brackish-water Theodoxus fluviatilis f. littoralis (at Vihterpalu $8 \%$, at Võlla $13.5 \%$ of all molluscs), which suggests the opening of the connection with the ocean and transition to the Mastogloia environment (Кессел \& Раукас, 1967).

The similarity of freshwater molluse fauna at different depths and in different parts of Partsi gravel pit suggests similar palaeoecological conditions during the accumulation of lithologically different facies. The medium-grained sand at a height of $8.7-12.5 \mathrm{~m}$ in the lowermost part of Ancylus sediments was dominated by Lymnaea baltica $(60.7 \%)$ and Bithynia tentaculata $(18.4 \%)$, with the accompanying species being Valvata piscinalis $(6.7 \%)$, Pisidium amnicum $(6.2 \%)$, Ancylus fluviatilis $(5.5 \%)$, and Sphaerium nitidum $(2.5 \%)$ (Pl. II, fig. 1$)$.

In the gravelly facies, $12-15 \mathrm{~m}$ above the present sea level, only hardly identifiable broken pieces of shells were often found. Shells have preserved well only in the interlayers of fine-grained sediments. In the total of more than a hundred well-preserved shells Lymnaea baltica $(83.1 \%)$ prevailed. Ancylus fluviatilis $(6.8 \%)$ and Bithynia tentaculata $(6.1 \%)$ were less frequent. E. Tavast has identified only some tiny shells of Lymnaea stagnalis, Valvata piscinalis, V. cristata, and Sphaerium nitidum.

In the overlying Litorina sands at a height of 15.6-17.8 m, typical brackish-water molluscs (PI. II, fig. 2), mainly different Cerastoderma species (probably C. glaucum $46.5 \%$ and $C$. edule $32.1 \%$ ), with some addition of Macoma baltica (13.6\%), Hydrobia ulvae $(5.1 \%)$, and Littorina littorea $(1.1 \%)$, were determined. Some brackish-water shells were found also at a height of $18-19.8 \mathrm{~m}$.

\section{CHRONOLOGY}

The chronology of the Baltic Sea history in Estonia is well established and based on a lot of ${ }^{14} \mathrm{C}$ dates obtained on lagoonal sediments and organic matter buried under transgressive beach formations. The sandygravelly deposits, which were studied in the Partsi section, did not contain any organic matter and, therefore, the only methods directly applicable for dating purposes were ${ }^{14} \mathrm{C}$ (on shells), infrared stimulated luminescence (IRSL) (on minerals, such as quartz and feldspars), and electron spin resonance (ESR) (on shells). The ${ }^{14} \mathrm{C}$ and IRSL methods used in dating Ancylus sediments from the height, considerably lower than the maximum level of this lake as accepted in Öland and Gotland, have yielded ages from c. $13425-13025$ yr BP (or $11260 \pm 190$ uncal. ${ }^{14} \mathrm{C}$ yr BP), as determined on shells (Königsson \& Possnert, 1988), to $7000 \mathrm{yr}$ BP, as determined by IRSL on feldspar grains (Königsson et al., 1995). These data show that the possibilities of the methods applied are rather limited. As to the results of ${ }^{14} \mathrm{C}$ (including AMS) dating, this is not surprising at all, since shells (and bones) are known as the worst dating material because of possible contamination by nonrepresentative carbon from the environment (see e.g. Olsson, 1974). According to some authors, thin-walled freshwater mollusc shells are entirely unsuitable for ${ }^{14} \mathrm{C}$ dating (see e.g. Goslar et al., 1986), owing to possible contamination of the shell material during sampling, handling, storing, preparation or in the nature before sampling. Besides, a high percentage of the mollusc shell carbonate is due to metabolic carbon incorporation into mollusc organism (see e.g. Tanaka et al., 1986). Part of the carbon in the shell carbonate can be derived from ambient water with dissolved infinitely old carbon from the calcareous bedrock that can cause the overestimation of the apparent ${ }^{14} \mathrm{C}$ age. These factors make it difficult to use $\delta^{13} \mathrm{C}$ values 


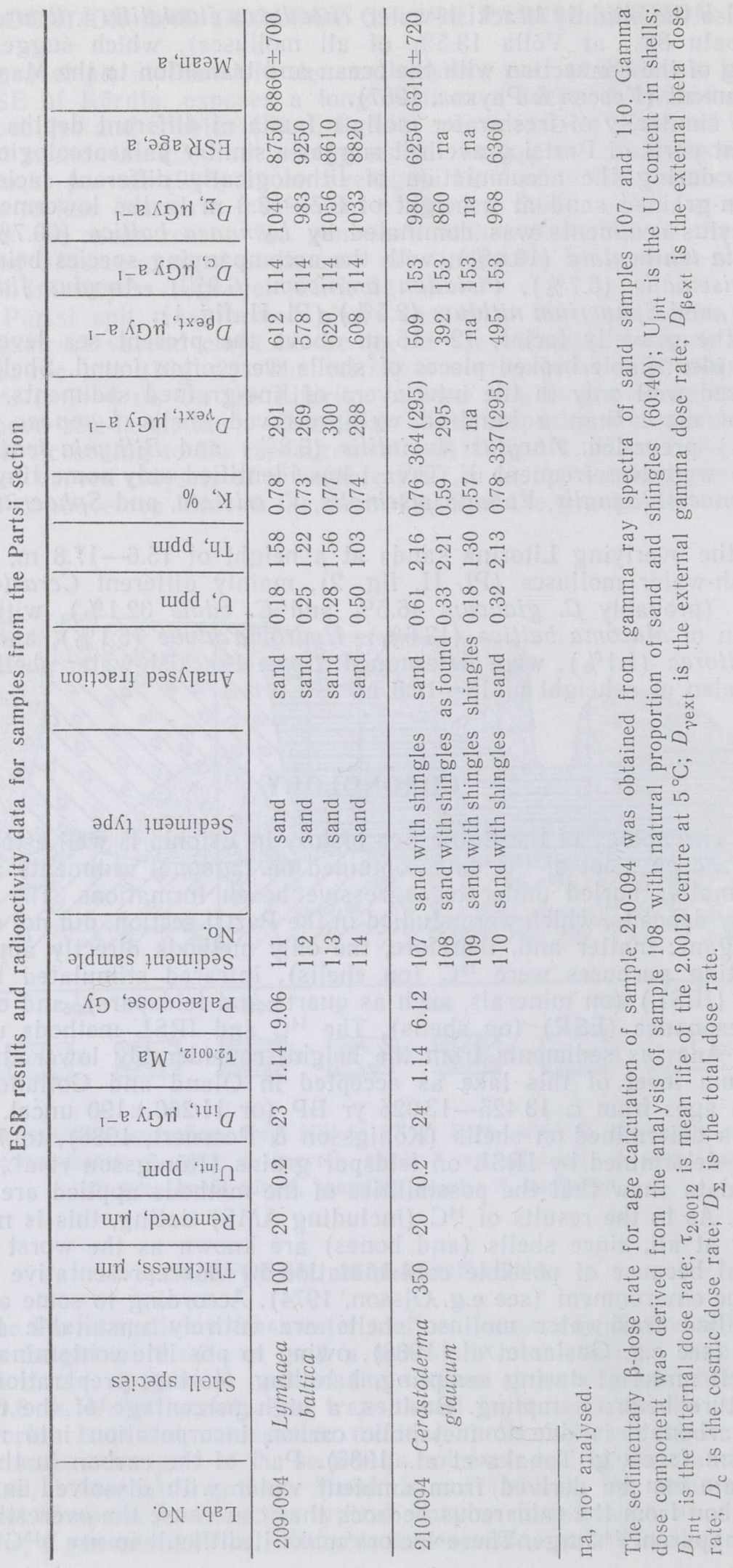




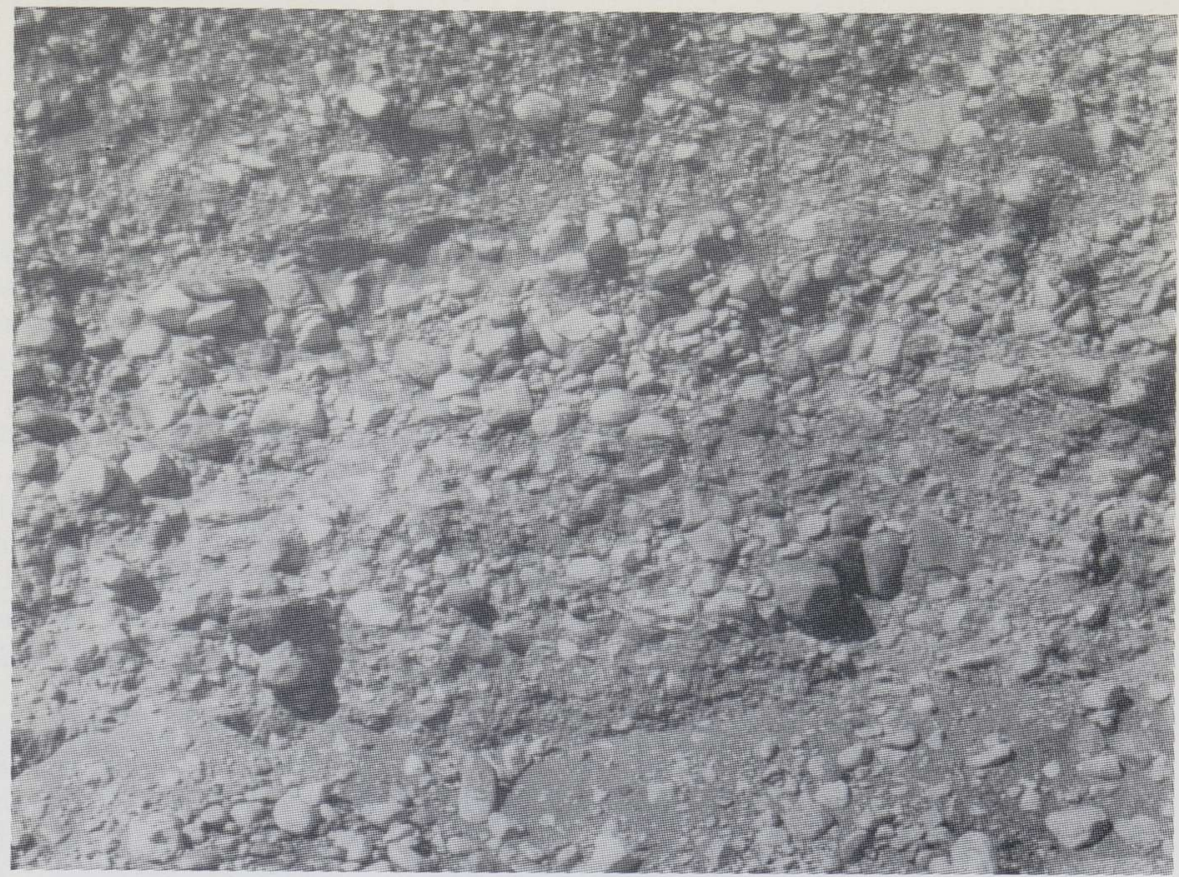

1. Pebbles and cobbles in the Partsi area are rather isometric. Photo by A. Raukas.

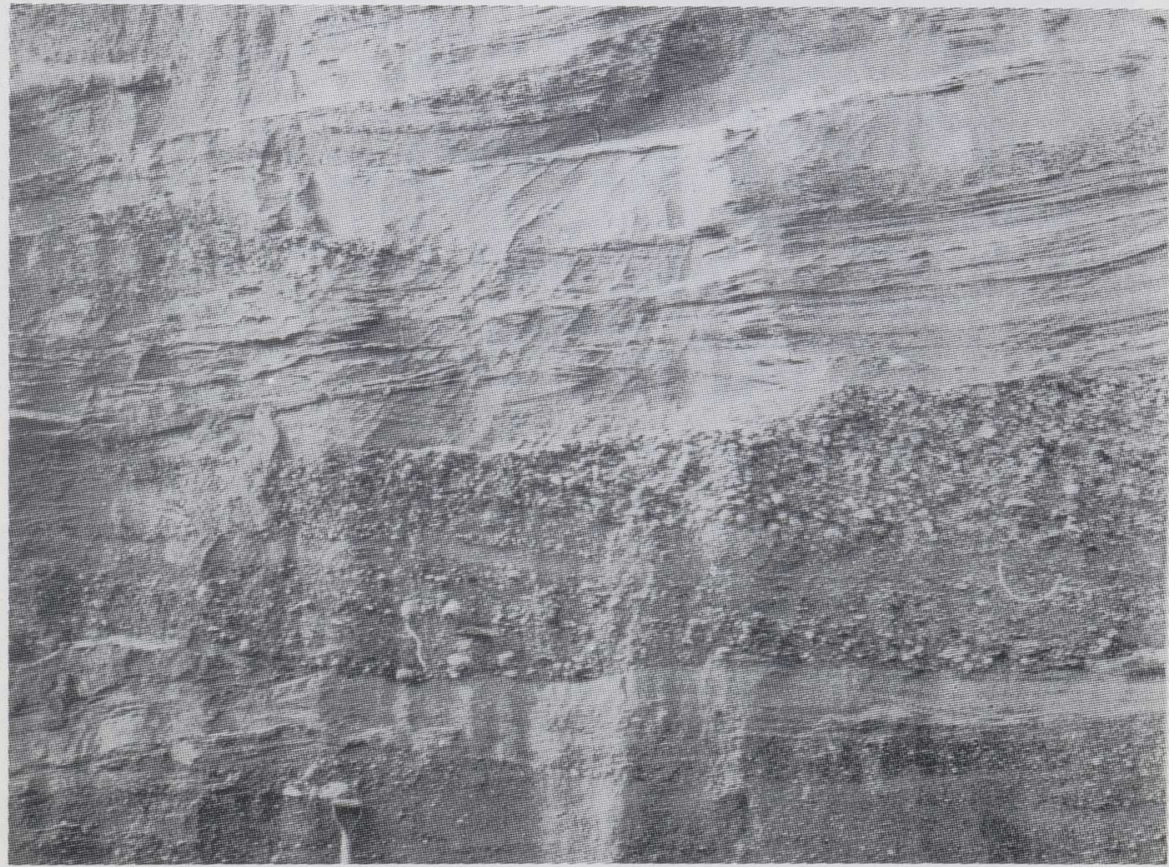

2. Stratification of medium-grained sand and gravel with westward dipping in the western part of Partsi gravel pit. Photo by A. Raukas. 
PLATE II

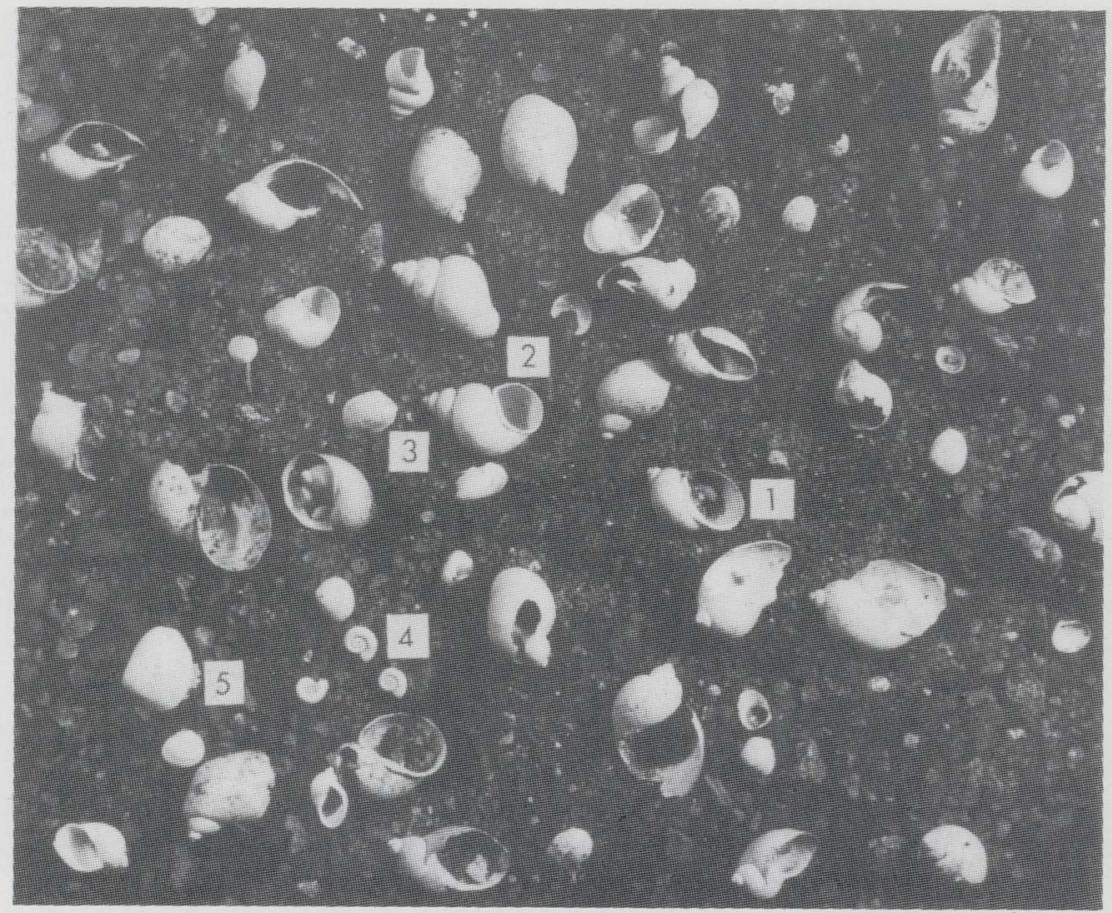

1. Characteristic Ancylus Lake subfossil mollusc fauna in Partsi gravel pit: 1, Lymnaea baltica; 2, Bithynia tentaculata; 3, Ancylus fluviatilis; 4, Valvata cristata; 5, Sphaerium nitidum.

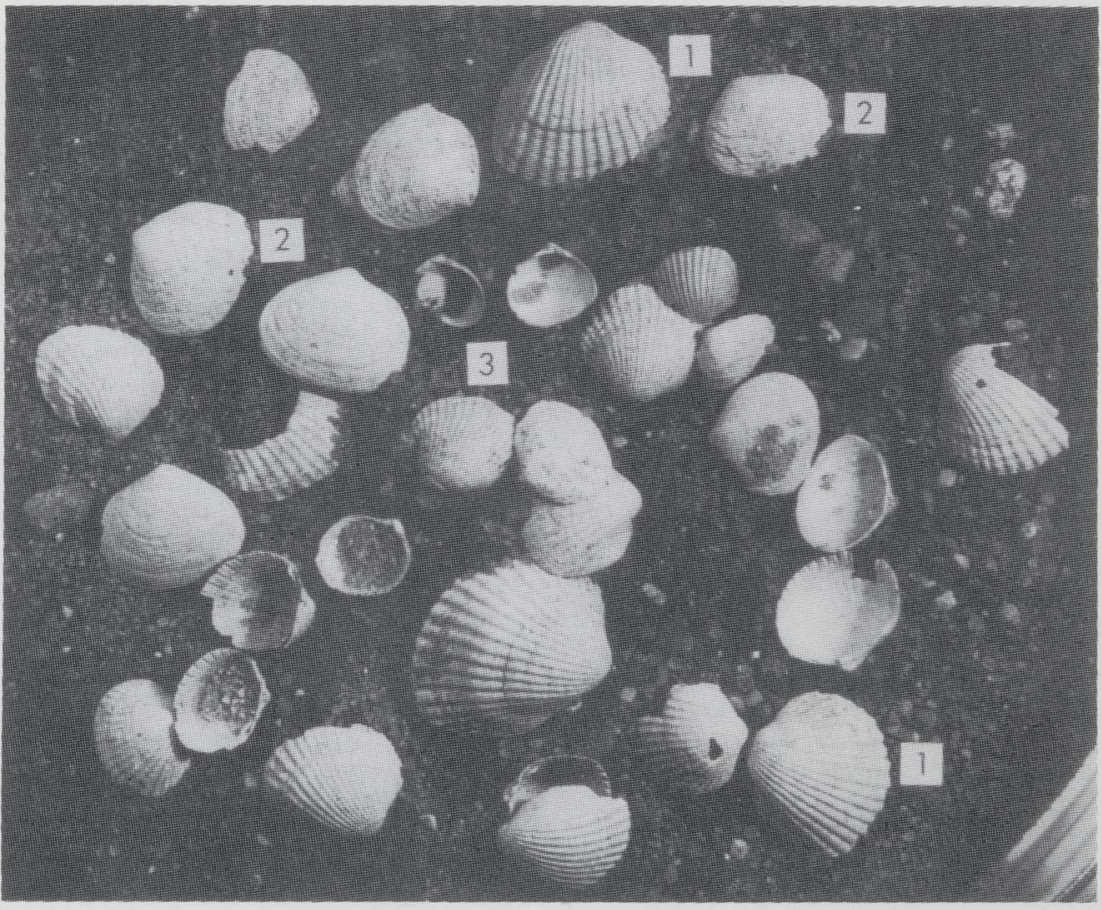

2. Characteristic Litorina Sea subfossil mollusc fauna in Partsi gravel pit: 1, Cerastoderma glaucum; 2, Macoma baltica; 3, Scrobicularia plana. 
of biogenic carbonate in molluse shells to predict the palaeoenvironmental conditions and to indicate the isotopic composition of ambient water in which molluses grew.

In several cases the IRSL method, first proposed by Godfrey-Smith et al. $(1987,1988)$, can also be applied to dating Holocene sediments. This dating method is based on a new luminescence readout technique using infrared diodes with $\lambda=880 \mathrm{~nm}$ (Godfrey-Smith et al., 1987, 1988) to stimulate electrons from light-sensitive traps in quartz and feldspars. Although almost all other steps in the optically stimulated luminescence dating procedure are similar to those employed in the conventional TL dating of unheated sediments, the new readout technique is able to use light-sensitive traps for dating, because loss of the electrons when exposed to direct sunlight may be of very short duration, and hence the residual signals for modern sediments can be easily zeroed (Huntley et al., 1985). However, subaqueous sediments seem not to be the best objects for the IRSL dating because the use of wavelengths outside the range $c .500$ to $625 \mathrm{~nm}$ would be inappropriate for zeroing the residual signals due to strong attenuation of the shorter and longer wavelengths by water (see e.g. Berger, 1988). At the same time, the results obtained in the field of ESR palaeodosimetry (see e.g. Molodkov, 1986, 1988, 1989, 1993) and ESR dating of marine, freshwater, and terrestrial mollusc shells performed under a proper stratigraphical control (see e.g. Molodkov \& Raukas, 1988; Молодьков et al., 1992; Molodkov, 1995a), hold out the hope that age determinations by the ESR will yield rather reliable results.

In the present work we have focused our attention on the dating of the freshwater gastropod Lymnaea baltica from the Ancylus complex and the brackish-water Cerastoderma glaucum species. The calculation for the Lymnaea baltica shell samples has yielded an average ESR age of $8860 \pm$ 700 yr BP (Molodkov, 1995b) (Table), which corresponds to about 8000 conventional uncalibrated radiocarbon years $\mathrm{BP}$ and is consistent with the expected age of the maximum Ancylus regression phase $A_{V I}$ or the transitional Mastogloia phase in the southern part of the Gulf on Finland (Хюваринен et al., 1992).

Age calculation of the Cerastoderma glaucum shell samples from the Litorina complex gave an average ESR age of $6310 \pm 720$ yr BP (Molodkov, $1995 \mathrm{~b}$ ) (or about 5500 uncal. ${ }^{14} \mathrm{C}$ yr BP). It fits with the chronological data available on the Litorina Stage $\left(7200-4200\right.$ uncal. ${ }^{14} \mathrm{C}$ yr BP; Hyvärinen et al., 1988). At the same time, as evidenced by X-ray diffraction data, about $10 \%$ of C. glaucum shell carbonate has changed its original aragonite composition to calcite. This would result in a slight underestimation of the age due to a probable loss of age information.

\section{DISCUSSION}

Königsson (Königsson \& Olsson, 1981; Königsson \& Possnert, 1988) explains the presence of freshwater mollusc shells in deposits $20-25 \mathrm{~m}$ below the Ancylus transgression limit in Öland and Gotland with redeposition from the sediments of the Baltic Ice Lake or, based on ${ }^{14} \mathrm{C}$ dates, relates them to the early part of the Ancylus transgression (the ${ }^{14} \mathrm{C}$ dates referred below are given as conventional uncalibrated radiocarbon dates $\mathrm{BP})$. The recent material from the Partsi section in Hiiumaa clearly demonstrates that this freshwater mollusc fauna found in low-lying Ancylus sediments belongs in situ to the end of Ancylus time or to the subsequent transitional Mastogloia (Clypeus) Stage. 


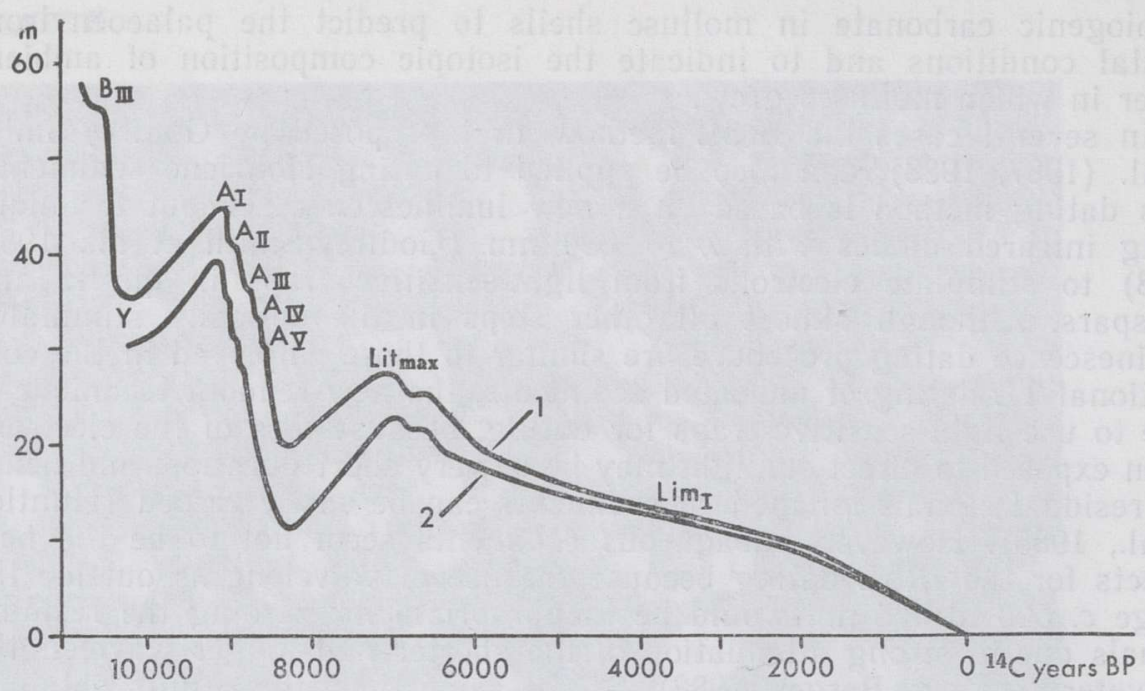

Fig. 3. Water level changes of the Baltic Sea at Kõpu (1) and Partsi (2).

The evidence derived from the Partsi section suggests a low water level on the boundary of Early and Late Boreal about 8500 years ago (Raukas \& Ratas, 1995) (Fig. 3), when the oceanic waters started to penetrate into the Baltic basin. According to Kessel and Raukas (Кессел \& Pаукас, 1967), the drop in water level in mainland Estonia was 20$25 \mathrm{~m}$, while the data from the Partsi section show the relative lowering by about $30 \mathrm{~m}$.

During the second half of the Boreal, the ocean should have gradually transgressed the Danish Straits, but only a minor quantity of the oceanic water could penetrate further to the east, where slightly brackish-water conditions appeared between $8000-7500{ }^{14} \mathrm{C}$ yr BP in littoral diatom records (Хюваринен et al., 1992). The Mastogloia/Litorina transgression culminated at different times in different areas, so that the peak was delayed towards the margins of the land uplift zone (Кессел \& Раукас, 1984). In Hiiumaa, the transgression culminated at about $7000{ }^{14} \mathrm{C}$ yr BP. In the areas with zero uplift the transgression trend naturally continued longer, until the eustatic sea level kept on rising.

Both the Ancylus and the Litorina mollusc iauna at Partsi are characteristic of the nearshore environment. Therefore, in the tectonically rising area the presence of Litorina nearshore molluscs above those of Ancylus age can be explained only by an abrupt lowering of the Ancylus Lake level before the Litorina transgression, whose sediments covered the Ancylus ones.

According to Eronen \& Ristaniemi (1992), the rapid transgression of the Ancylus Lake began soon after $9600{ }^{14} \mathrm{C}$ and reached maximum level about $9300{ }^{14} \mathrm{C}$ yr BP, when a new discharge channel opened in the southwest, apparently via the Great Belt in Denmark. According to Estonian materials, the maximum of the Ancylus transgression took place about 9200-9000 ${ }^{14} \mathrm{C}$ yr BP (Raukas et al., 1995) and the regression could have started not later than $8900-8800{ }^{14} \mathrm{C}$ yr BP. It ended with the onset of the Mastogloia Stage sometime between 8500 and $8000{ }^{14} \mathrm{C} \mathrm{yr}$ BP. Taking into consideration that the Ancylus limit, which is fixed at a height of about $40 \mathrm{~m}$ at Partsi, reached its maximum here some 9200$9000{ }^{14} \mathrm{C}$ yr BP, and the minimum of the Ancylus regression at a height of about $12 \mathrm{~m}$ occurred approximately $8200-8000{ }^{14} \mathrm{C}$ yr BP, then the rate 
of the Ancylus Lake regression should have been on an average about $3-4 \mathrm{~cm}$ per year. It is difficult to evaluate precisely the role of land uplift in the shore displacement. For example, in NW Estonia the Preboreal land uplift was on an average about $1.3 \mathrm{~cm}$ per year (Paykac, 1978). On the other hand, the evidence derived from ancient shorelines shows that during postglacial time Hiiumaa Island has risen some $45 \mathrm{~m}$, i.e. $c$. $4.5 \mathrm{~mm}$ per year. However, changes in the gradients of shorelines suggest (Кессел \& Мийдел, 1973) that the uplift was uneven and the rate of land upheaval decreased abruptly at the end of the Atlantic. It means that up to one third $(9-10 \mathrm{~m})$ of the relative lowering of water level could have been caused by land uplift. Anyway, an abrupt drop in water level well accounts for the presence of a distinct boundary between the transitional clays and postglacial muds in the Baltic offshore sediments, considered as a boundary between the Ancylus and Litorina stages (Ignatius et al., 1981).

\section{ACKNOWLEDGEMENTS}

The authors wish to thank Mrs. Elle Puurmann and Dr. Urve Ratas for assistance with fieldwork and the collecting of samples, Messrs. Harri and Tanel Moora for the levelling works, Dr. Avo Miidel for fruitful discussions, Mrs. Helle Kukk for linguistic improvements, Mr. Paul Pärkma for the drawings and Mr. Gennadi Baranov for photos of mollusc shells. The research was financially supported by grants 326 and 971 from the Estonian Science Foundation and the PACT Project "Environmental History of the Baltic Region".

\section{REFERENCES}

Berger, G. W. 1988. Dating Quaternary events by luminescence. - In: Clark, P. U. and Lea, P. D. (eds.). The Last Interglacial-Glacial Transition in North America: Boulder, Colorado. Geol. Soc. Am. Spec. Pap., 270, 13-50.

Eronen, M., Ristaniemi, O. 1992. Late Quaternary crustal deformation and coastal changes in Finland. - Quat. Int., 15/16, 175-184.

Godfrey-Smith, D. I., Huntley, D. J., Chen, W.-H. 1987. The optical behavior of quartz and feldspar sediment extracts. - 5th International Specialist Seminar on TL and ESR Dating, Cambridge (oral comm.).

Godfrey-Smith, D. I., Huntley, D. J., Chen, W.-H. 1988. Optical dating studies of quartz and feldspar sediment extracts. - Quat. Sci. Rev., 7, 373-380.

Goslar, E., Goslar, T., Pazdur, M. 1986. Datowanie metoda ${ }^{14} \mathrm{C}$ kosci i muszli - problemy metodyki i interpretacji wynikow. - Zesz. nauk. PSI. Mat.-Fiz., 46, 71-82.

Huntley, D. J., Godfrey-Smith, D. I., Thewalt, M. L. W. 1985. Optical dating of sediments. - Nature, 313, 105-107.

Hyvärinen, H., Donner, J., Kessel, H., Raukas, A. 1988. The Litorina Sea and Limnea Sea in the northern and central Baltic. - In: Donner, J. and Raukas, A. (eds.). Problems of the Baltic Sea History. Ann. Acad. Sci. Fennicae, AIII, 148, 25-35.

Ignatius, H., Axberg, S., Niemistö, L., Winterhalter, B. 1981. Quaternary Geology of the Baltic Sea. - In: Voipio, A. (ed.). The Baltic Sea. Elsevier, AmsterdamOxford-New York, 54-104.

Kents, P. 1939. Postglatsiaalsed Läänemere randjoone võnkumised Eestis illustreeritud Kõpu poolsaarel. Magistritöö. Käsikiri Tartu Ulikoolis.

Königsson, L.-K., Olsson, I. U. 1981. Radiocarbon dating of Ancylus faunas 20-25 m below the Ancylus limit of Öland and Gotland. - Striae, 14, 163-166.

Königsson, L.-K., Possnert, G. 1988. Ancylus fauna studied by acceleration ${ }^{14} \mathrm{C}$ dating of single small shells. - Geol. Surv. Finland, Spec. Pap. 6, 137-145. 
Königsson, L.-K., Possnert, G., Hütt, G. 1995. Early Baltic sea-level history based on AMS-dating of small mollusc shells. - J. Coast. Res., Special Issue 17. Holocene Cyclic Pulses and Sedimentation, 921-925.

Molodkov, A. 1986. Application of ESR method to the dating of subfossil shells from marine deposits. - Ancient TL, 4, 49-54.

Molodkov, A. 1988. ESR dating of Quaternary shells: Recent advances. - Quat. Sci. Rev., 7, 477-484.

Molodkov, A. 1989. The problem of long-term fading of absorbed palaeodose on ESRdating of Quaternary molluse shells. - Appl. Radiat. -Isot., 40, 1087-1093.

Molodkov, A. 1993. ESR-dating of non-marine mollusc shells. - Appl. Radiat. Isot., 44, $145-148$.

Molodkov, A. 1995a. ESR dating evidence for early man at Triangular Cave in the Northern Caucasus. - PACT, Rixensart (in press).

Molodkov, A. 1995b. ESR dating of brackish-water molluse shells: Unusual Cerastoderma glaucum specimens. - In: Fill, U. and Regulla, D. (eds.). Final Programme and Book of Abstracts. 4th International Symposium on ESR Dosimetry and Applications. GSF-Forschungszentrum, Munich/Neuherberg, 1519 May 1995, 144.

Molodkov, A., Raukas, A. 1988. The age of Upper Pleistocene marine deposits of the Boreal transgression on the basis of electron-spin-resonance (ESR) dating of subiossil molluse shells. - Boreas, 17, 267-272.

Olsson, I. U. 1974. Some problems in connection with the evaluation of ${ }^{14} \mathrm{C}$ age. Geol. Fören. Stockh. Förh., 96, 311-320.

Raukas, A., Bird, E., and Orviku, K. 1994. The provenance of beaches on the Estonian islands of Hiiumaa and Saaremaa. - Proc. Estonian Acad. Sci. Geol., 43, 2, $81-92$.

Raukas, A., Ratas, U. 1995. Evolution and palaeoenvironmental conditions of Hiiumaa Island (NW Estonia) in Holocene. - PACT, Rixensart (in press).

Raukas, A., Kimmel, K., and Rajamäe, R. 1995. A new site of buried peat at Lõpe, SW Estonia. -Proc. Estonian Acad. Sci. Geol., 44, 2, 133-137.

Tanaka, N., Monaghan, M. C., Danny, M. R. 1986. Contribution of metabolic carbon to mollusc and barnacle shell carbonate. - Nature, 320, 520-523.

Tavast, E. 1995. Subfossiilsed molluskid Hiiumaa vanades rannasetetes. Hiiumaa loodus. - In: Kukk, T. (ed.). XVIII Eesti looduseuurijate päev. Ettekanded. Hiiumaa, 22.-23. juuli 1995. Teaduste Akadeemia Kirjastus, Tartu-Tallinn, 12-17.

Кессел Х., Мнйдел А. 1973. О поздне- и послеледниковых движениях земной коры на территорин Эстонии. - Изв. АН ЭССР. Хим. Геол., 22, 3, 257-264.

Кессел Х. Я., Раукас А. В. 1967. Прибрежные отложения Анцилового озера и Литоринового моря в Эстонии. Валгус, Таллинн.

Қессел Х., Раукас А. 1984. О геологической корреляции древнебереговых образований Балтийского моря в Эстонии и Швеции. - Изв. АН ЭССР. Геол., 33, 3/4, $146-157$

Молодьков А. Н., Раукас А. В., Макеев В. М., Барановская О. Ф. 1992. К ЭПР-хроностратиграфии морских отложений Северной Евразии и их корреляции с событиями плейстоцена. - In: Мурзаева В. Э., Пуннинг Я.-М. К., Чичагова О. А. (eds.). Геохронология четвертичного периода. Наука, Москва, 41-46.

Раукас А. В. 1978. Плейстоценовые отложения Әстонской ССР. Валгус, Таллинн.

Хюваринен Х., Раукас А., Кессел Х. 1992. Мастоглойевое и Литориновое моря. - In: Раукас А., Хюваринен Х. (eds.). Геология Финского залива. АН Эстонии, Таллинн, 296-312. 


\title{
PARTSI - LÄÄNEMERE UUS PERSPEKTIIVNE HILISBOREAALSE JA VARAATLANTILISE VEETASEME MUUTUSTE UURIMISE PIIRKOND
}

\section{Anto RAUKAS, Elvi TAVAST, Anatoli MOLODKOV}

Kirde-Hiiumaal Paluküla aluspõhjakõrgendiku distaalosas paiknev Partsi liivik ja kruusaauk on unikaalne koht, kus neotektooniliselt kerkivas piirkonnas subfossiilset malakofaunat sisaldavad Litoriinamere setted katavad Antsülusjärve setteid. Seejuures paiknevad viimased $30 \mathrm{~m}$ madalamal Antsülusjärve maksimaalsest levikupiirist Hiiumaal. Elektronparamagnet-resonantsmeetodil saadi Antsülusjärve setetest kogutud Lymnaea baltica kodade vanuseks $8860 \pm 700$ aastat (vastab umbes 8000 radiosüsiniku aastale) ja Litoriinamere setetest kogutud Cerastoderma glaucum'i kodade vanuseks $6310 \pm 720$ aastat (vastab umbes 5500 radiosüsiniku aastale). Seega langeb Antsülusjärve veetaseme järsu alanemisega seotud miinimum üleminekulisse Mastogloia staadiumisse. Kuivõrd Antsülusjärve regressiooni aegne maapinna kerge Hiiumaal võis olla ligikaudu $10 \mathrm{~m}$, saab basseini väljavoolust tingitud vahetuks veetaseme languseks Partsi kohal pidada umbes $20 \mathrm{~m}$. Järsk veetaseme alanemine põhjendab hästi selget litoloogilist piiri Antsülusjärve ja Litoriinamere põhjasetete vahel Läänemeres ning ka näiliselt anomaalset setete levikupilti Partsi kruusaaugus.

\section{ПАРТСИ - НОВЫЙ ПЕРСПЕКТИВНЫЙ РАЙОН ДЛЯ ИССЛЕДОВАНИЯ ПОЗДНЕБОРЕАЛЬНЫХ И РАННЕАТЛАНТИЧЕСКИХ КОЛЕБАНИИ УРОВНЯ БАЛТИЙСКОГО МОРЯ}

\author{
Анто РАУКАС, Эльви ТАВАСТ, Анатолий МОЛОДЬКОВ
}

Расположенные в северо-восточной части о-ва Хийумаа в районе Партси гравийно-галечные отложения являются уникальными для всей Балтики. Здесь на неотектонически поднимающейся территории более молодые литориновые отложения покрывают анциловые, причем последние залегают на 30 м ниже максимального уровня Анцилового озера. Определенный ЭПР-методом возраст раковин пресноводного моллюска Lymnaea baltica из анциловых отложений соответствует $8860 \pm 700$ годам, или примерно 8000 годам по некалиброванной радиоуглеродной шкале. Возраст створок раковин моллюска Cerastoderma glaucum из литориновых отложений составляет $6310 \pm 720$ лет, что соответствует примерно 5500 годам по некалиброванной шкале ${ }^{14} \mathrm{C}$. Таким образом, резкий спад вод и минимальный уровень Анцилового озера близки по времени к переходному Мастоглойевому морю. Поскольку поднятие земной коры за время регрессии Анцилового озера на о-ве Хийумаа можно оценить примерно в 10 м, то спад уровня озерных вод за довольно непродолжительное время составил порядка 20 м, что объясняет четкую литологическую границу между донными отложениями Анцилового озера и Литоринового моря, а также аномальное залегание отложений в районе Партси. 